policy on biotechnology as ambitious as the information technology policy embodied in the Esprit programme still awaiting political approval and financial blessing. In the meantime, however, the concertation unit would establish and maintain a network of experts, strengthening the present arrangements for coordination on biotechnology among the ten member states.

\title{
Small companies star
}

ONE theme running through the Office of Technology Assessment (OTA) report is the importance to US biotechnology of the newly formed specialist companies of which more than 200 are listed in the report. OTA says that these appear to be more productive of research-based innovation than established companies when compared person for person, and that they have a tendency to bring research results to the market more quickly than better established companies. The report notes, however, that newly formed companies, launched with private funds or by means of a public offering, may find the problems of refinancing more difficult when their initial capital is used up, if only because investors in new companies necessarily look for good returns. This opinion appears to have been written before the onset of the fall in the value of biotechnology stocks last autumn.

In an analysis of 18 US biotechnology companies whose shares are publicly traded, OTA points out that only three (Cetus, Genentech and International Genetic Engineering) had positive earnings in the latest complete financial year and that two of these were in that happy position because of interest earned from funds obtained in public offerings. OTA notes that the high cost of financing research programmes has persuaded many companies to finance their operations through research contracts with larger companies or to recruit capital by means of limited partnerships in respect of research and development projects. For similar reasons many companies are giving priority to the development of products that will have an immediate market, such as monoclonal antibodies for the diagnosis of disease and veterinary products and feed additives for livestock.

In spite of the publicity given to biotechnology, OTA points out that venture capital is still flowing more strongly into the fields of communications, computers and electronics, which consumed nearly 60 per cent of investments in 1982 . One striking feature of the pattern of investment in the past few years has, however, been the willingness of established US companies to invest in their smaller brethren. In 1982, the total investment in new biotechnology companies from this source is estimated to have been $\$ 120$ million but to have fallen to $\$ 40$ million in 1983 , chiefly because of the increasing attention paid by the larger companies to strengthening their own in-house activities.

Looking ahead, OTA says that new companies may ultimately suffer from these ar- rangements because of the low profit margins to be expected from patent royalties, the chance that research contracts will not be renewed and the willingness of the larger partners in research contracts to devote resources to the exploitation and marketing of new products. For these reasons, OTA concludes, successful biotechnology companies will in due course find it necessary to engage in the whole range of activities bearing on the exploitation of their innovation.

On the links between universities and industrial companies, new or well established, OTA notes that there are advantages for both partners as well for the "national innovative process". At the same time, it points out that universities cannot expect that royalty income from patents will ever be a substantial part of their current costs. On the basis of a questionnaire sent out to university administrators, teachers and students, OTA comes to the conclusion that the reduction of federal funds for universities has been a spur, that few difficulties have arisen in the conduct of these relationships, and that 85 per cent of respondents considered that links with industry had not damaged university research.

\section{West Germany More adventure from capital}

OBSTAClES to technology transfer and the formation of new companies in West Germany could be swiftly removed if a motion tabled in the Bundestag by two parties of the government coalition (the Christian Democratic Union, CDU, and the Free Democratic Party, FDP) is adopted. The need to improve the position of small and medium-sized companies in the Federal Republic is confirmed by the dim view of European investment in biotechnology taken by the US Office of Technology Assessment (OTA) (see page 402).

Although the stock market recently reached an all-time high and West Germany is still a leading world exporter, its share of world trade has fallen. Except for a few traditional areas such as chemicals, automobiles and electronics, the country has become an importer of high technology. More companies are going bankrupt than are starting up whence the interest in the search for means to encourage the formation of new high technology companies.

A major part of the problem is recognized to be the dependence of West German industry on loan capital rather than equity (risk) capital, which at present accounts for only 20 per cent of the capital employed by public companies, with a mere 5 per cent representing savings by members of the public. The banks, the main source of capital and the only insti-

\section{Profile of a company start-up by venture capital}

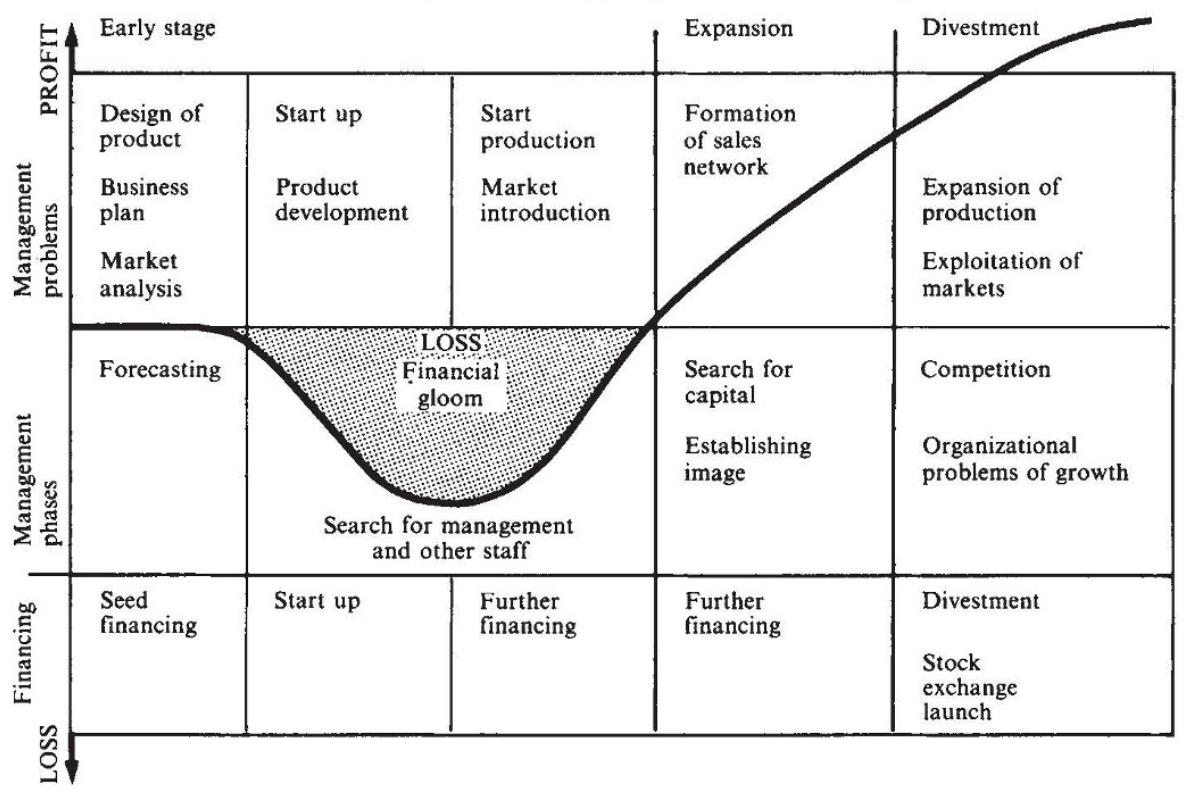

VENTURE capitalism combines financing with management and technical expertise. The investors take an active role in the development of the company. Misjudgement, takeover, merger or loss of crucial staff are a few "risks" that would give a different profile. A successful investor can hope to see this picture emerge for one third of his ventures; one third would level off to a low profit; one third would be written off. A reasonable time would be five years. 